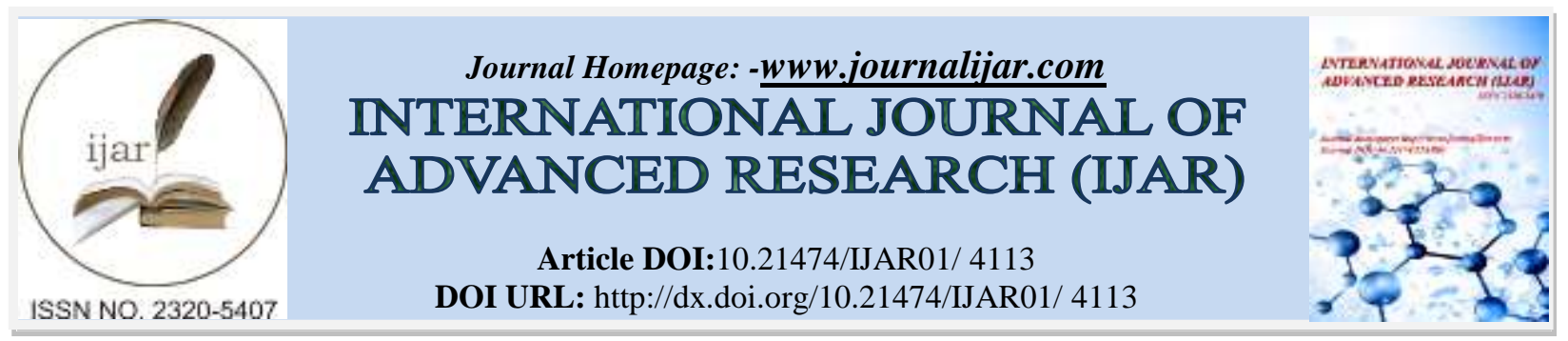

RESEARCH ARTICLE

\title{
RECONSTRUCTION OF CRIMINAL PROCEDURE CODE OF INDONESIA ON THE SUBJECTIVE REASONS OF DETENTION BASED ON DIGNIFIED JUSTICE
}

Muhammad Khambali.

Faculty of Law, Cokroaminoto University Yogyakarta, Jalan Perintis Kemerdekaan Gambiran Umbulharjo Yogyakarta Indonesia kode pos 55161

\section{Manuscript Info}

Manuscript History

Received: 12 March 2017

Final Accepted: 13 April 2017

Published: May 2017

Key words:-

Detention, Justice, Pancasila.

\section{Abstract}

Within detention there is a conflict between two principles: the right of one's human rights which must be respected on the one hand, and the interests of public order on the other side which must be preserved for the people or society of the criminal acts of the suspect or defendant. Therefore, detention should be done if necessary once. The subjective terms of detention (noodzakelijkheid) do not yet contain the value of justice, especially the first, second, and fifth principles of Pancasila. The reconstruction of the rules of detention in Indonesian criminal procedure code (Law of the Republic of Indonesia Number 8 of 1981 on Criminal Procedure Code) is refined by altering, adding or even removing it based on the value of dignified justice based on Pancasila. The purpose of the reconstruction is to protect all parties, either suspects or defendants, victims, the community including the families of suspects or defendants, victims, officials authorized to arrest, as well as the state. At the same time to prevent the dominance of the subjectivity of officials authorized to arrest.

Copy Right, IJAR, 2016,. All rights reserved.

\section{Introduction:-}

The amended 1945 Constitution confirms in article 1 paragraph (1) that the state of Indonesia is a unitary state in the form of a republic. Article 1 paragraph (2) provides that the sovereignty of the people is in the hands of the people and is carried out in accordance with the Constitution. While article 1 paragraph (3) determines that the state of Indonesia is a state law. The third paragraph in article 1 of the 1945 Constitution shows that the state of Indonesia is a unitary state in the form of a republic, sovereignty is in the hands of the people and based on law (rechtstaat) not based on mere power (machtstaat).

As a rule of law, both rulers and citizens, even the state itself must all submit to the law. All attitudes, behavior, and deeds must be appropriate or lawful. The source of the law is the sense of law within the community 
itself. ${ }^{1}$ According to Plato, good state governance is a government based on good legal arrangements, and governance based on law is one good alternative in the administration of the state. ${ }^{2}$

The state of Indonesia as an independent state of law must develop its own national law characterized by the character and soul of the Indonesian (Volkgeist) personality. Indonesian national law is a law within the national scope that is built from the results of the efforts of the Indonesian nation based on and based on the basic philosophy of the ideology of Pancasila. ${ }^{3}$

Indonesian law is still much affected by the laws of Dutch origin. That's because the Netherlands for hundreds of years colonize the state of Indonesia. Even today there are still many laws that come from the Netherlands used. Soehino has said: ${ }^{4}$

Proclamation of Indonesian Independence on August 17, 1945 is a starting point for the Indonesian people in order to realize Pancasila as the source of all sources of law.

The above has been argued that based on the Proclamation of Indonesian Independence dated August 17, 1945 stands the state of Indonesia's independence, and at the same time also the birth of the Indonesian legal system. This means that from then on a formal form no longer applies the old law, the rule of the Dutch East Indies. However, since the Constitution of the newly independent State of Indonesia was only adopted on August 18, 1945, in order to overcome the absence or occurrence of legal vacuum, we have to put forward the phrase of the Proclamation of Independence dated August 17, 1945 which reads: "Matters concerning transfer of power and others are held in a careful way and in the shortest possible time ", as a transitional rule.

After 72 years of independent state of Indonesia, there are still many Dutch laws used, for example in material law still using the Criminal Code derived from Wetboek van Straafrecht (WvS), whereas Wetboek van Straafrecht itself in the Netherlands has been repeatedly revised. In certain cases in Indonesia still use the Criminal Code derived from Burgerlijk Wetboek (BW). Similarly, in civil cases still use the Dutch law of the Herziene Indische Reglement (HIR) for Java and Madura, and Rechtreglement voor de Buitengewesten (RBg) for outside Java and Madura.

According to Sudikno Mertokusumo, by virtue of its functions the law is divided into substantive law and formal law (adjective law): ${ }^{5}$

Based on the criteria of legal function is divided into substantive law and formal law (adjective law). In the event of a violation of law, then the violated material law must be enforced. To enforce the material law requires the rule of law whose function is to implement or enforce the material law, that is formal law. Formal law determines how to implement material law, how to realize rights and obligations in the event of any violation of law or dispute. Formal law is the rule of the judge's game in examining and deciding cases in court. Material law requires formal law. If the legal system has only a material law and does not have formal law, then in the event of conflict or violation of the material law will open the opportunity to conduct an act of self-judgment (eigenrichting), will occur arbitrary action from the party who feel harmed. The Indonesian legal system also recognizes two kinds of formal law, namely formal civil law and formal criminal law.

Prior to the coming into effect of the Criminal Procedure Code, the formal criminal law is HIR as a guideline for the State Court in both civil cases and civilian criminal cases in Java and Madura. For District Courts outside Java and Madura apply RBg. Since HIR is deemed not to provide legal guarantees for the Indonesian nation, the Criminal Procedure Code, contained in the State Gazette of the Republic of Indonesia Number 76, Supplement to the State Gazette Number 3209, to replace HIR.

1 Khambali, Muhammad, 2014, "Fungsi Filsafat Hukum Dalam Pembentukan Hukum Di Indonesia”, Jurnal Supremasi Hukum, Fakultas Syariah dan Ilmu Hukum Universitas Islam Negeri Sunan Kalijaga Yogyakarta,Volume 3, Nomor 1, p. 2.

2 Teguh Prasetyo\& Arie Purnomosidi, 2014, Membangun Hukum Berdasarkan Pancasila, Bandung: Nusa Media, p. 1.

$3 \quad$ Ibid, p. 5-6.

4 Soehino, 1992, Hukum Tatanegara, Sejarah Ketatanegaraan Indonesia, Yogyakarta: Liberty, p. 17-18.

5 Sudikno Mertokusumo, 2007, Mengenal Hukum, Yogyakarta: Liberty, p. 127. 
The Criminal Procedure Code raises fundamental changes, both conceptually and implementationally to the settlement of criminal cases in Indonesia. With the enactment of the Criminal Procedure Code, all previous laws and regulations as long as regulate the implementation of criminal procedure law are revoked. In the Criminal Procedure Code has laid the foundations of humanism and is a new era in the judicial environment in Indonesia. The Criminal Procedure Code is a national criminal procedure which is based on the philosophy of Pancasila and the 1945 Constitution.

The Criminal Procedure Code stipulates principal matters, the principles of Indonesian criminal procedural law, namely: the principle of legality, the principle of opportunism, equality before the law principle, presumption of innocence, arrest, detention, search and seizure are conducted on the written orders of the competent authority, the principle of indemnification and rehabilitation, the principle of quick, simple and light tuition, the suspect or defendant is entitled to legal assistance, the principle of trial examining criminal cases by the presence of defendants, court is open to the public, the principle of accusatoir (placement of suspects as subjects).

In the case of the detention of a suspect or a defendant in criminal procedure law has a weakness, so the investigator is too easy to decide to hold someone. Investigators still use the maximum detention mechanism to the maximum extent of detention that is allowed by the legislation even if it has found sufficient evidence. This resulted in places of detention in Indonesia full and over capacity. Should the detention be the last alternative to a suspect or a defendant a crime.

Detention, which in principle is a limitation of human rights, conducted by investigators and prosecutors without a court of law, makes detention difficult to control. Although there are pre-trial institutions, most of the legal efforts through pre-trial institutions are unsuccessful. The practice of transferring types of detention and also the suspension of detention by the use of legal counsel (advocate) is often also aggravated. It is for the subjective reason that the authorities authorized to carry out the detention are concerned that the suspect or defendant is uncooperative at the time of the examination, so that the official in charge of detention overrides the application for the transfer of detention or suspension of detention.

Officials authorized to carry out detention, in accordance with the provisions of Article 20 of the Criminal Procedure Code, are:

1. Investigator.

2. Prosecutor.

3. Judge, only extend the detention conducted by the prosecutor.

This indicates that the rules of detention of suspects or defendants in the Criminal Procedure Code still have weaknesses, in the form of conflict or vague or legal vacuum.

Detention is a form of deprivation of one's freedom of movement. Within detention there is a conflict between two principles: the right of one's human rights which must be respected on the one hand, and the interests of public order on the other side which must be preserved for the people or society of the criminal acts of suspects or defendants. Therefore, detention should be done if necessary once. The mistakes in detention can result in fatalities for many parties including arrest. ${ }^{6}$

Article 21 of the Criminal Procedure Code regulates the validity as well as the need for detention. Theories distinguish the validity (rechwaardigheid) and the necessity (noodzakelijkheid) of detention. The rethare (rechwaardigheid) of detention is objective and absolute, meaning that it can be seen in the law what delays can be made against the suspect or defendant. Whereas the necessity (noodzakelijkheid) of detention is relative because it determines whether or not detention is necessary, depending on the appraisal of the competent authority who will make the detention.

The provisions concerning the validity (rechwaardigheid) of detention are included in article 21 paragraph (4) of the Criminal Procedure Code, whereas the need (noodzakelijkheid) of detention is included in article 21 paragraph (1) of Criminal Procedure Code. Article 21 paragraph (1) of the Criminal Procedure Code stipulates that the order of

6 Andi Hamzah, 2001, Hukum Acara Pidana Indonesia, Jakarta: Sinar Grafika, hlm 127. 
detention or further detention of a suspect or defendant suspected of having committed a crime on the basis of sufficient evidence, is based on the concern of a suspect or defendant:

1. escape.

2. damage or eliminate evidence.

3. repeat offenses.

Article 31 of the Criminal Procedure Code regulates the suspension of detention, that at the request of the suspect or defendant, the investigator or the public prosecutor or judge, in accordance with their respective authorities, may hold the suspension of arrest with or without the security of money or guarantees of persons, on the conditions specified. Officials authorized to suspend suspects or defendants shall be investigators or public prosecutors or judges in accordance with their respective authorities in their detention.

Therefore, between the authorities authorized to do or not to arrest, the transfer of types of detention, and the suspension of the detention of a suspect or a defendant resides in one institution or institution, it gives an opportunity to the competent authority to withhold, transfer the type of detention, suspend the detention by irregularities by detention of suspects or defendants arbitrarily or even beyond the authority. The act of detention may also serve as a "buy-sell" commodity by means of detention of a suspect or defendant then "transact" to suspend the detention or transfer of a type of detention with a certain "price".

Based on the background description of the aforementioned problem, that the detention of suspects or defendants may not bring about justice, so the detention of a suspect or a defendant may result in a negative impact.

\section{Discussion:-}

Reconstruction of the detention or suspect's detention law in this research is the reconstruction of legislation regulating the detention including the suspension of detention and transfer of types of detention to the suspect or defendant. Reconstruction of the Criminal Procedure Code, especially regarding detention including suspension of detention of suspects or defendants, is intended to restructure fundamentally or to arrange for better retention in the implementation of detention, including suspension and transfer of types of detention of suspects or defendants based on fairness and benefit value, just to achieve legal certainty.

According to the United Nations Human Rights Committee, pre-trial detention (detention of a suspect or defendant) should be used only if the action is legitimate, reasonable and necessary. Detention may be necessary to prevent the defendant from escaping, obstructing proof or repetition of a criminal offense, or if the person carries a serious, serious threat to a society that can not be prevented in any other way. ${ }^{7}$

The United Nations Human Rights Committee has also established that the detention of suspects or defendants should not be arbitrary. The intent of arbitrary should not be equated with violating the law, but it must be interpreted more broadly to include elements of inaccuracy, injustice, unpredictability and the absence of fair judicial proceedings. Consequently, the detention of a suspect or a defendant must not only be legally valid but also natural and necessary for any circumstances. ${ }^{8}$

In the other country, it can be seen that what sets the issue of detention of a suspect or a defendant is a judge. In the history of criminal procedure law in Indonesia, once introduced by the term of the judge commissioner as contained in the Reglement op de Strafvoerdering, it is set in the second title of Van de regter-commissaris functioning at the preliminary examination stage to oversee whether the action forced efforts (dwang middelen), which include arrest, searches, seizure and inspection of letters, whether legally or not. ${ }^{9}$ However, in its development, since the introduction of Herziene Indische Reglement (HIR) with Staatsblad. 44 In 1941, the term regtercommissaris was not used anymore.

7 Human Rights and Pre-Trial Detention. A Handbook of International Standards relating to Pre-Trial Detention, Professional Training Series No. 3 (New York: United Nations, 1994), p. 14-15

8 Ibid.

9 Badan Pembinaan Hukum Nasional (BPHN), 2011, Hakim Komisaris dalam Sistem Peradilan di Indonesia,p. 1. 
The universal right to detain a person is a judge. Because the nature of detention is a violation of human rights in the form of freedom of movement, it is the judge who determines whether a person is legitimate and needs to be detained.

The implementation of a state of law in accordance with the 1945 Constitution absolutely requires a legislative instrument that upholds human rights and guarantees every citizen simultaneously his position in law and government and shall uphold such law and government with no exception. Similarly, in the field of criminal procedural law as the basis for the implementation of a fair and humane justice in a jurisdiction, it is deemed necessary to provide a set of legislation that guarantees the enforcement of criminal law in accordance with the function and authority of each law enforcement apparatus in the direction of law, justice, And the protection of human dignity, order, and legal certainty. ${ }^{10}$

Legal reform is essentially part of the policy (rational effort) to renew legal substance in order to make the law enforcement more effective, to protect the community, and to overcome social problems and humanitarian problems in order to achieve social welfare.

The renewal of the criminal procedure law can not be separated from the idea of building a national legal system based on Pancasila as the life philosophy of the Indonesian nation. This means that the renewal of the criminal procedural law should be sourced and oriented to the basic idea of Pancasila which contains values: divinity, humanity, nationality, democracy and social justice.

In order for the law to function properly as a protector and protector of society, the law should always be able to adjust to the development and dynamics of community aspirations. Therefore the law must always be renewed, so that the law is actually dynamic in accordance with the circumstances and needs of the community. In this connection Pancasila is a source of value for the renewal of law which according to Notonagoro domiciled as Staatsfundamentalnorm in the state of Indonesia. ${ }^{11}$

The values contained in the five precepts of Pancasila is a principle of living together from various elements of the nation community in realizing the ideals of life with prosperity, peace, justice and social justice. The value of divinity and humanity is the basis of ethics underlying common life in the united state of the Republic of Indonesia, in realizing the democratic life that originates in the sovereignty of the people with the morality of deliberate deliberations, so that with the wisdom will manifest a civilized and dignified democracy of humanity, and in realizing a life Together with justice. It may be taken to mean that the ethical values contained in Pancasila derive from the values of God and the value of natural law contained in the values of Pancasila. ${ }^{12}$

The basic principle of ethics in realizing legal justice as embodied in the principles of Pancasila, is contained in the principles of the basic values of divinity, humanity, and justice in the social life of the state of Indonesia. Ontologically, therefore, the basic value of justice in Pancasila philosophy is derived from the human essence of "monopluralism". A civilized human being is a human being who must realize justice in relation to other human beings, nation and state society, just in human relations with his environment and human beings must be fair in relationship with God Almighty. ${ }^{13}$

The theory of dignified justice is an activity of philosophical thought, which can also be done by a judge when a judge gives legal consideration to his decision. The process of legal formation under the microscope of the theory of dignified justice, thus, is a scientific process in the field of law concerning the positive legal knowledge of Indonesia. Thus, the theory of dignified justice can also be seen as a contextual form of the abstraction of knowledge of positive law of Indonesia, or theory of knowledge with the object of the material is the knowledge of positive law.

10 Al. Wisnubroto \& G. Widiartana, 2005, Pembaharuan Hukum Acara Pidana, Bandung: PT Citra Aditya Bakti, p. 1.

11 Notonagoro, 1995, Pancasila Secara Ilmiah Populer, Jakarta: Bumi Aksara, p. 31.

12 Kaelan, 2011, Filsafat Pancasila, Yogyakarta: Paradigma, p. 72.

13 Notonagoro, 1995, op. cit., p. 50. 
A positive legal system seen as a material object rather than a dignified justice theory is a legal system based on the first agreement, or Pancasila. ${ }^{14}$

The theory of dignified justice departs from postulate system; work towards the goal, that is dignified justice. Justice that humanize man, or justice ngewongke wong. ${ }^{15}$ As is known, the legal empire is the imperium of reason, the intention and the sense of a human child, wherever he is living his life. The source of justice in the theory of dignified justice is the meeting point between the "upper stream", God's thinking and the "undercurrent", the Indonesian Volksgeist in Pancasila; continue the mandate of the Proclamation of Indonesian Independence. This is in line with the principle of a dignified justice theory that cares about taking advantage of God-given opportunities for him to help others through thinking; humanize human or ngewongke wong. ${ }^{16}$

Prior to the reconstruction of the detention of suspects or defendants in the Criminal Procedure Code which the investigator needs to be reconstructed, the following: article 21 paragraph (1) Criminal Procedure Code: Any order of detention or continued detention shall be committed against a suspect or defendant allegedly committed a crime based on sufficient evidence The existence of circumstances that cause concern that the suspect or defendant will flee, destroy or eliminate the evidence and/or repeat offenses.

Analysis of the detention of suspects or defendants in the Criminal Procedure Code: The regulation of detention of a suspect or defendant contained in article 21 paragraph (1) of the Criminal Procedure Code is a subjective requirement for the detention (noodzakelijkheid) of a suspect or defendant has not included the value of justice, The value of equilibrium and divine value. The subjectivity of the officials in charge of detention is very dominant, and has not been based on the value of justice, especially the value of dignified justice based on the first, second and fifth principles of Pancasila.

The reconstruction of the detention of the suspect or defendant in the Criminal Procedure Code is refined by altering, adding, or even abolishing the following: Detention or extension of further detention or detention of a suspect or defendant suspected of committing a crime on the basis of sufficient evidence and alleged allegation of suspect Or the defendant will:

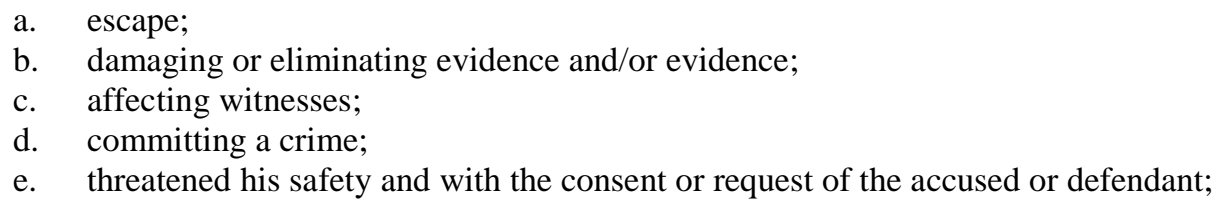

\section{Conclusion:-}

Based on the foregoing, the conclusions of the reconstruction of detention rules against suspects or defendants based on dignified justice value are as follows:

\section{Basic Reconstruction:- \\ Local Wisdom:-}

The values contained in the 1st, 2nd, and 5th Precepts of Pancasila, as well as

The 1945 Constitution in particular: article 27 paragraph (1), Chapter X A on Human Rights Article 28A-Article 28J, Chapter XI Religion Article 29.

\section{International Wisdom:-}

International Covenant for Civil and Political Rights (ICCPR) or the International Covenant on Civil and Political Rights; as well as

The Universal Declaration of Human Rights established by the United Nations.

Findings: The weakness of the detention rules against the suspects or defendants contained in article 21 paragraph (1) of the Criminal Procedure Code is the subjective requirement for the detention (noodzakelijkheid) against the

\footnotetext{
14 Teguh Prasetyo, 2015, Keadilan Bermartabat, Perspektif Teori Hukum, cetakan pertama, Bandung: Nusa Media, p. 16-17.

15 Ibid, p. 2.

16 Ibid, p. 22.
} 
suspect or the defendant has not included the value of divinity, humanity and justice. The subjectivity of the officials in charge of detention is very dominant, and has not been based on the value of justice, especially the value of dignified justice based on the first, second and fifth principles of Pancasila.

Recommendation of the ideal value of article 21 paragraph (1) of the Criminal Procedure Code is based on the values of dignified justice based on the first, second and fifth principles of Pancasila aimed at protecting all parties, either suspects or defendants, victims, communities including suspects or families defendants and victims, officials authorized to detain, as well as the state, while preventing the dominance of the subjectivity of officials authorized to arrest.

Reconstruction of article 21 Paragraph (1) of the Criminal Procedure Code, as follows: Detention or further extension of detention or continued detention of a suspect or defendant suspected of committing a crime on the basis of sufficient evidence and allegedly suspect or defendant shall:

a. escape;

b. damaging or eliminating evidence and / or evidence;

c. affecting witnesses;

d. committing a crime;

e. threatened his safety and with the consent or request of the accused or defendant;

\section{References:-}

1. Al. Wisnubroto \& G. Widiartana, 2005, Pembaharuan Hukum Acara Pidana, Bandung: PT Citra Aditya Bakti.

2. Andi Hamzah, 2001, Hukum Acara Pidana Indonesia, Jakarta: Sinar Grafika.

3. Badan Pembinaan Hukum Nasional (BPHN), 2011, Hakim Komisaris dalam Sistem Peradilan di Indonesia.

4. Human Rights and Pre-Trial Detention. A Handbook of International Standards relating to Pre-Trial Detention, Professional Training Series No. 3 (New York: United Nations, 1994).

5. Kaelan, 1996, Filsafat Pancasila, Yogyakarta: Paradigma.

6. Khambali, Muhammad, 2014, "The Functions of Legal Philosophy in Legal Formation in Indonesia", Journal of Law Supremacy, Faculty of Sharia and Law of the State Islamic University of Sunan Kalijaga Yogyakarta, Volume 3, Number 1.

7. Notonagoro, 1995, Pancasila Secara Ilmiah Populer, Jakarta: Bumi Aksara.

8. Soehino, 1992, Hukum Tatanegara, Sejarah Ketatanegaraan Indonesia, Yogyakarta: Liberty.

9. Sudikno Mertokusumo, 2007, Mengenal Hukum, Yogyakarta: Liberty.

10. Teguh Prasetyo\& Arie Purnomosidi, 2014, Membangun Hukum Berdasarkan Pancasila, Bandung: Nusa Media.

11. Teguh Prasetyo, 2015, Keadilan Bermartabat, Perspektif Teori Hukum, cetakan pertama, Bandung: Nusa Media. 